\title{
Numerical Analysis on Stability of Caisson-Type Breakwaters under Tsunami-Induced Seepage
}

\author{
Yutaka Sawada $^{1} \cdot$ Michio Miyake ${ }^{2}$. \\ Junji Miyamoto $^{2} \cdot$ Toshinori Kawabata $^{1}$
}

\begin{abstract}
In this study, distinct element method (DEM) analysis and slip analysis based on the simplified Bishop method have been carried out in order to investigate stability of a caisson-type breakwater under tsunami-induced seepage and establish the design method of the caisson foundation. The effect of seepage on the bearing capacity of the caisson foundation was introduced as the reduction of the effective weight of the rubble mound in the both analyses. As a result of the distinct element (DE) analysis, it has been revealed that the shear strain of the rubble mound increases due to the tsunami-induced seepage. Moreover, from the slope stability analysis, it has been indicated that the safety factor decreases by $7-10 \%$ due to the seepage force, which is approximately corresponding to the increase rates of shear deformation in DE analysis.
\end{abstract}

Keywords Caisson-type breakwater - Distinct element method - Slope stability analysis . Tsunami $\cdot$ Seepage

\section{Introduction}

Breakwaters are structures constructed for the purpose of protecting a harbor and an anchorage from waves. Many breakwaters were severely damaged by the Great East Japan Earthquake on March 11, 2011. The failure mechanism of a caisson-type breakwater subjected to a tsunami is significantly complicated since several factors (tsunami force, scour, and seepage force) are related to the collapse phenomenon as

\section{Yutaka Sawada}

sawa@harbor.kobe-u.ac.jp

1 Graduate School of Agricultural Science, Kobe University, 1-1 Rokkodai, Nada, Kobe, Hyogo 657-8501, Japan

2 Naruo Research Institute of Toyo Construction Co., Ltd., 1-25-1 Naruohama, Nishinomiya, Hyogo 663-8142, Japan 
shown in Fig. 1. To predict the performance of the breakwater against tsunami attacks, an investigation on the effects of each factor on the stability is essential.

The stability of a caisson-type breakwater subjected to a tsunami was investigated by numerical simulations and hydraulic model experiments $[1,2]$. However, the effect of the tsunami-induced seepage beneath the rubble mound on the stability has not been discussed.

Miyake et al. [3] conducted centrifuge model tests for a caisson-type breakwater subjected to a massive tsunami, and Imase et al. [4] performed numerical simulations for the centrifuge model tests using the smooth-particle hydrodynamics (SPH) method. From these studies, it has been concluded that the great seepage force occurs in the rubble mound during the tsunami attacks. However, the period of the tsunami was short since it was generated by dam-break method, and the effect of the seepage on the stability has not been clarified.

Dong et al. [5] carried out vertical loading tests for a caisson-type breakwater under a hydraulic head difference and investigated the reduction of the bearing capacity of the rubble mound due to the tsunami-induced seepage. However, the bearing capacity has been estimated on the basis of the settlement of the caisson, and the shear deformation of the mound has not been discussed. In addition, the effects of the seepage and the uplift force on the bearing capacity have not been clearly distinguished.

For these problems, Takahashi et al. [6] conducted lateral loading tests and finite element analysis for a caisson-type breakwater under seepage force. In order to evaluate the only effect of the seepage, the upward seepage was generated from the bottom of the container, and the component of uplift force was eliminated in the model test. As a result, it has been concluded that the reduction of the bearing capacity due to seepage is $17 \%$ when the hydraulic water difference is $10 \mathrm{~m}$. However, the upward seepage in the model test was larger than that in actual situations. Thus, it is assumed that the effect of seepage on the bearing capacity is overestimated. Additionally, although the bearing capacity depends on the location of the caisson, which is the distance from the edge of the mound [7], only a few cross sections has been investigated. Moreover, there remains issue of the bearing capacity at the large deformation of the rubble mound.

With the above-mentioned background, this paper aims to reveal the effect of tsunami-induced seepage on the bearing capacity in a quantitative way. For this purpose, a caisson-type breakwater laterally loaded has been simulated by twodimensional distinct element method (2D-DEM) [8]. In addition, for the purpose of

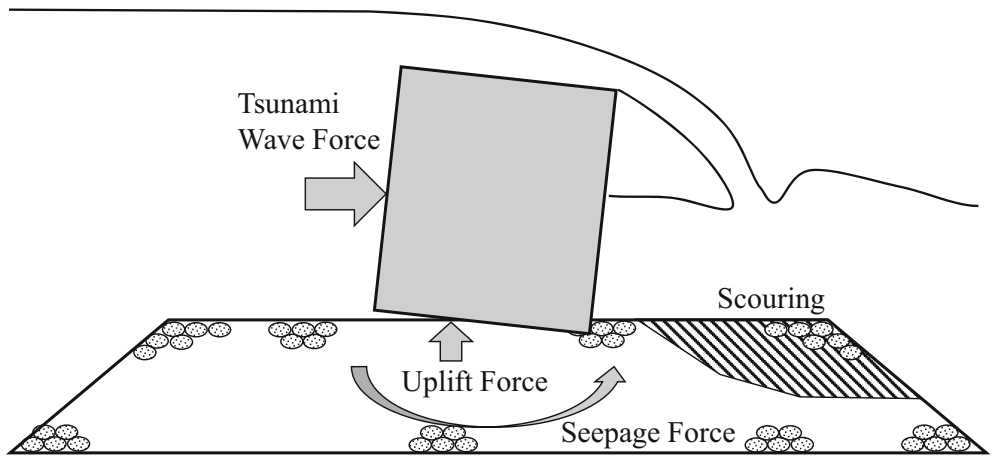

Fig. 1 Failure mechanism of a caisson-type breakwater 
the design of a rubble mound considering the seepage effect, the circular failure analysis based on the simplified Bishop method has been performed.

\section{D Distinct Element Analysis}

In general, it is difficult to simulate the large deformation and the collapse phenomenon of a caisson foundation by finite element methods. Moreover, in laboratory experiments, it is not possible to prepare exactly the same models for testing under various conditions. In this study, to simulate the large deformation behavior of a caisson foundation under tsunami attacks, the 2D DE analysis has been carried out, which is suitable to study the mechanics of granular materials. The DE model prepared in the present study is shown in Fig. 2, and the procedure of the investigation is indicated in Fig. 3. First, the parameters of DEM have been determined according to the results in a past study. Second, overflow simulations have been performed to evaluate the seepage force in the rubble mound and the uplift force on the caisson. Third, lateral loading simulations on the caisson have been performed considering the effect of the seepage using DEM.

\section{Determination of Parameters}

Generally, suitable parameters used in DE analysis are difficult to be determined on the basis of soil tests. The objective of this study is not to develop DEM as a prediction technique but to reveal the shear characteristics of the rubble mound subjected to seepage using DEM. Therefore, the parameters have been determined on the basis of the previous study, which was a series of model tests on a caisson-type breakwater with a reinforcement embankment by Kikuchi et al. [9] as shown in Fig. 4. Namely, the parameters were calibrated by trial and error method such that the relationships between the horizontal displacement and the lateral resistance were consistent with the experimental results. In the model tests, for the caisson model, a concrete box having a width

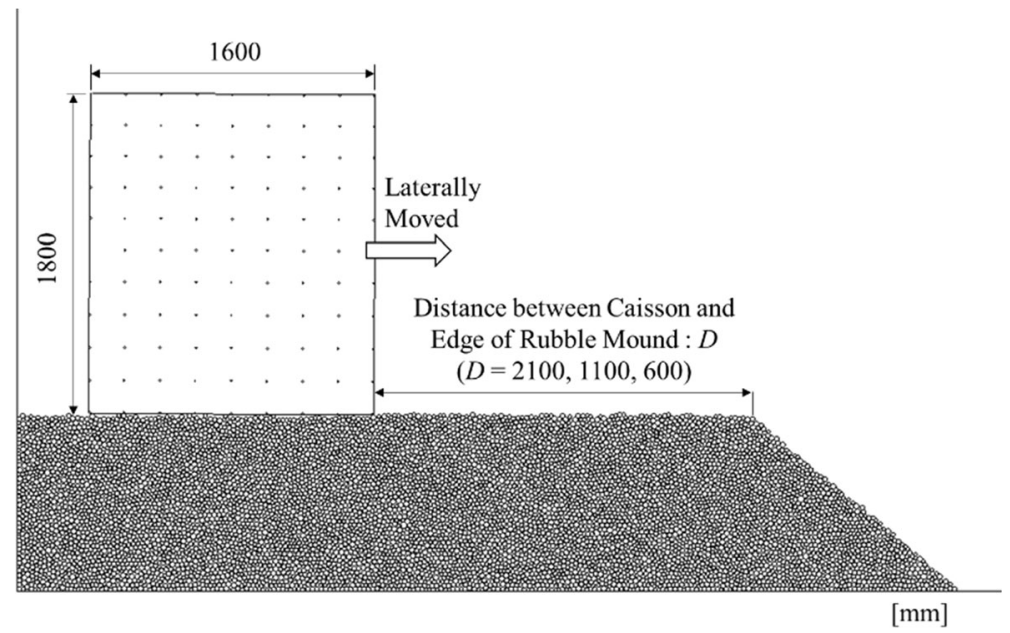

Fig. 2 DE model of a caisson-type breakwater 


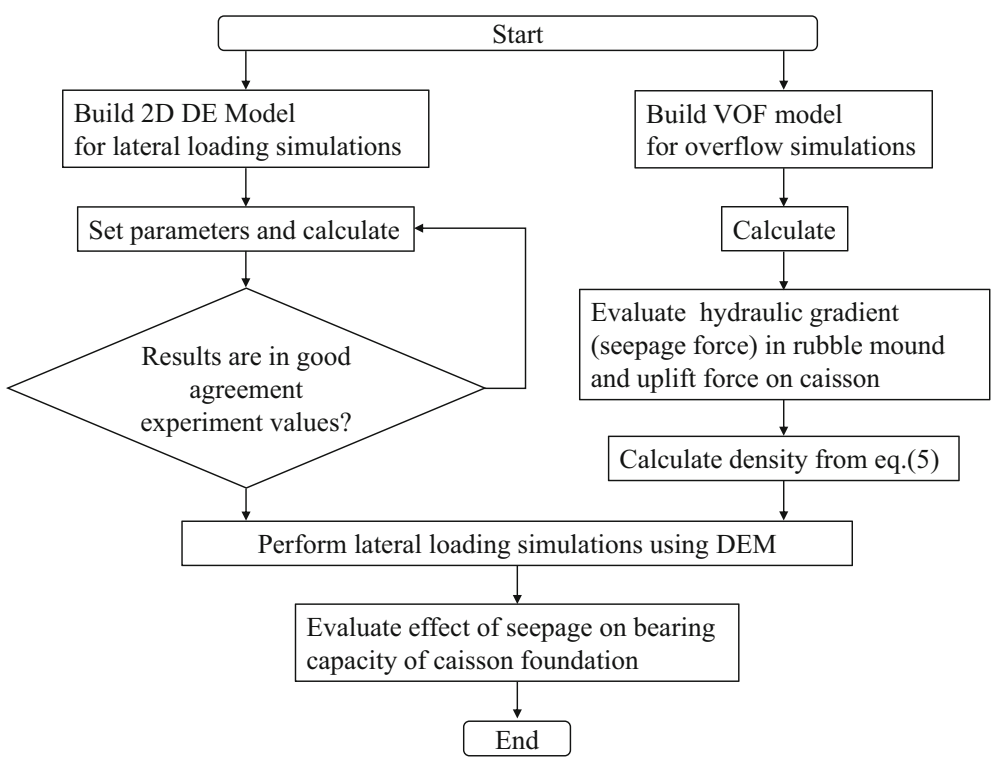

Fig. 3 Flowchart of investigation

of $1.6 \mathrm{~m}$, a height of $1.8 \mathrm{~m}$ and a depth of $2.0 \mathrm{~m}$ was used. The self-weight was $119 \mathrm{kN}$. For the rubble mound, gravel $\left(d=10\right.$ to $40 \mathrm{~mm}, U_{c}=1.3, \rho_{s}=2.651 \mathrm{~g} / \mathrm{cm}^{3}$, and $\gamma_{d}=$ $\left.15.1 \mathrm{kN} / \mathrm{m}^{3}\right)$ was used. The internal friction angle $\varphi$ was from $37.5^{\circ}\left(\sigma_{3}=392 \mathrm{kN} / \mathrm{m}^{2}\right)$ to $49^{\circ}\left(\sigma_{3}=49 \mathrm{kN} / \mathrm{m}^{2}\right)$. The caisson model was laterally loaded by a speed of $10 \mathrm{~mm} /$ min using a hydraulic jack at a height of $0.92 \mathrm{~m}$ from the bottom of the caisson. Further details on the model tests can be found in Kikuchi et al. [9].

The analysis involved the caisson and the rubble mound which had the same scales as the experimental models as shown in Fig. 2. As shown in Fig. 2, the model of caisson was composed of 99 particles and 36 beam elements. The particles were

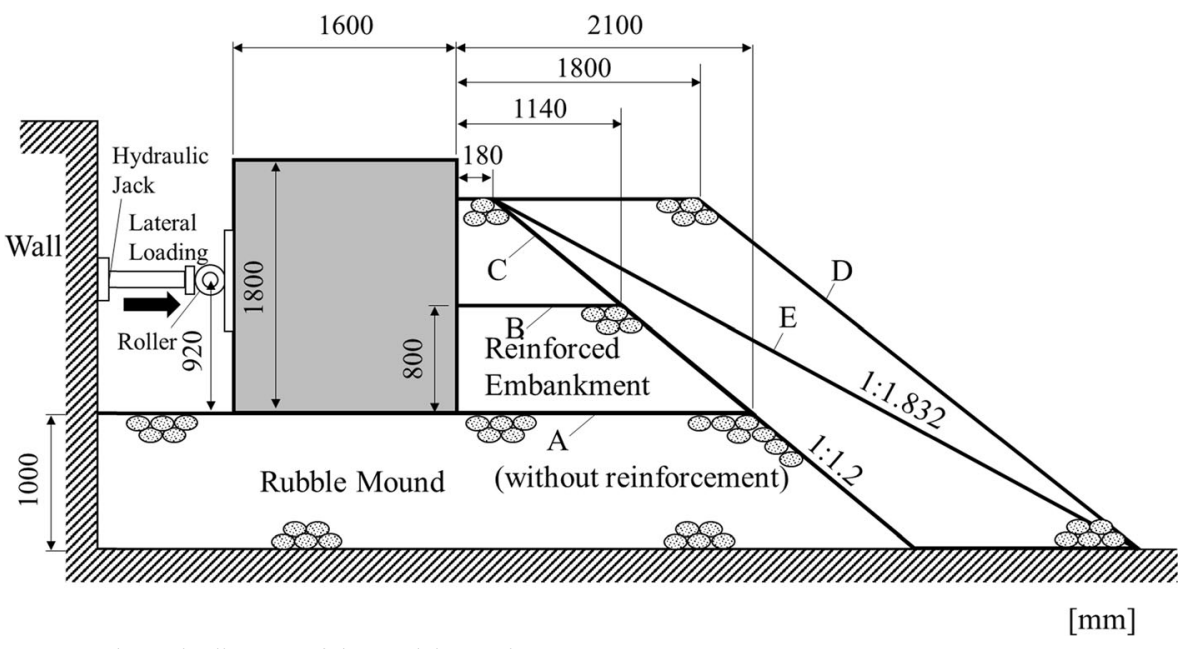

Fig. 4 Schematic diagram of the model experiment [9] 
Table 1 Parameters of the model of caisson

\begin{tabular}{ll} 
Particle diameter & $10.0 \mathrm{~mm}$ \\
Particle density & $5.4 \times 10^{5} \mathrm{~kg} / \mathrm{m}^{3}$ \\
Normal spring coefficient & $5.0 \times 10^{7} \mathrm{~N} / \mathrm{m}$ \\
Tangential spring coefficient & $1.25 \times 10^{6} \mathrm{~N} / \mathrm{m}$ \\
Normal damping coefficient & $2.11 \times 10^{3} \mathrm{Ns} / \mathrm{m}$ \\
Tangential damping coefficient & $8.02 \times 10^{-3} \mathrm{Ns} / \mathrm{m}$ \\
Friction coefficient between the surface of the breakwater and the particles & 0.62 \\
Cohesion & $0 \mathrm{kN} / \mathrm{m}^{2}$ \\
\hline
\end{tabular}

connected to each other by springs summarized in Table 1 . The structure behaves as a rigid body. The beam elements play a role as a boundary and provide the force on the model of caisson. The friction between the beam element and soil particles is 0.62 , which have been determined on the basis of the model test.

The procedure of preparing the analytical model is described as follows. First, the model of the rubble mound was obtained by free fall method. Second, extra particles were removed as the rubble mound was an appreciate shape. Third, the model of caisson was installed on the foundation. After the installation of the caisson, an initial analysis was performed until the stress reached the stable condition. After the preparation of the analytical model, the caisson was laterally moved up to $15 \mathrm{~mm}$ at a speed of $10 \mathrm{~mm} / \mathrm{s}$. The loading position was at the height of $0.92 \mathrm{~m}$ from the base of caisson and was also the same condition as the model tests. It is also approximately corresponding to the centroid of a tsunami pressure distribution.

Table 2 summarizes the calibrated parameters of the rubble mound. Figure 5 shows the relations between the average horizontal displacement and the horizontal resistance. Note that the horizontal resistance represents the total horizontal force on the beam elements of the caisson. The analytical results of horizontal resistance are in good agreement with experimental results.

Table 2 Parameters of soil particles

Average diameter

Uniformity coefficient

Particle density

Normal spring coefficient

Tangential spring coefficient

Normal damping coefficient

Tangential damping coefficient

Friction angle between particles

Rolling friction angle

Cohesion
$25.0 \mathrm{~mm}$

1.3

$2.4 \times 10^{3} \mathrm{~kg} / \mathrm{m}^{3}$

$7.20 \times 10^{7} \mathrm{~N} / \mathrm{m}$

$1.80 \times 10^{6} \mathrm{~N} / \mathrm{m}$

$4.60 \times 10^{3} \mathrm{Ns} / \mathrm{m}$

$1.75 \times 10^{-2} \mathrm{Ns} / \mathrm{m}$

$36.0^{\circ}$

$12.0^{\circ}$

$0 \mathrm{kN} / \mathrm{m}^{2}$ 


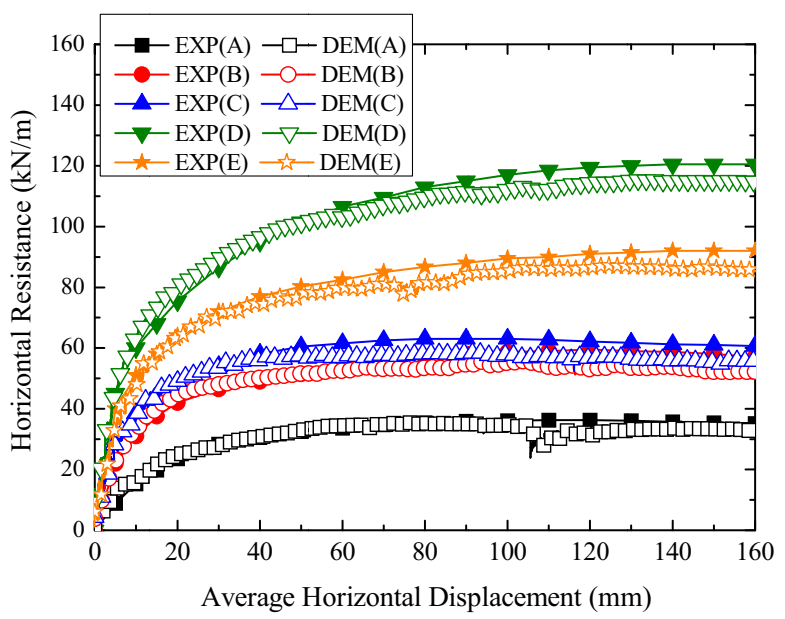

Fig. 5 Relations between the average horizontal displacement and the horizontal resistance

Figure 6 indicates the shear strain distributions at the horizontal displacement of $150 \mathrm{~mm}$. As shown in Fig. 7, shear strain is calculated from differences in average displacements in neighboring cells as follows:

$$
\gamma_{m n}=\frac{\left|u_{m+1, n}-u_{m, n}\right|}{d y}+\frac{\left|v_{m, n+1}-v_{m, n}\right|}{d x}
$$
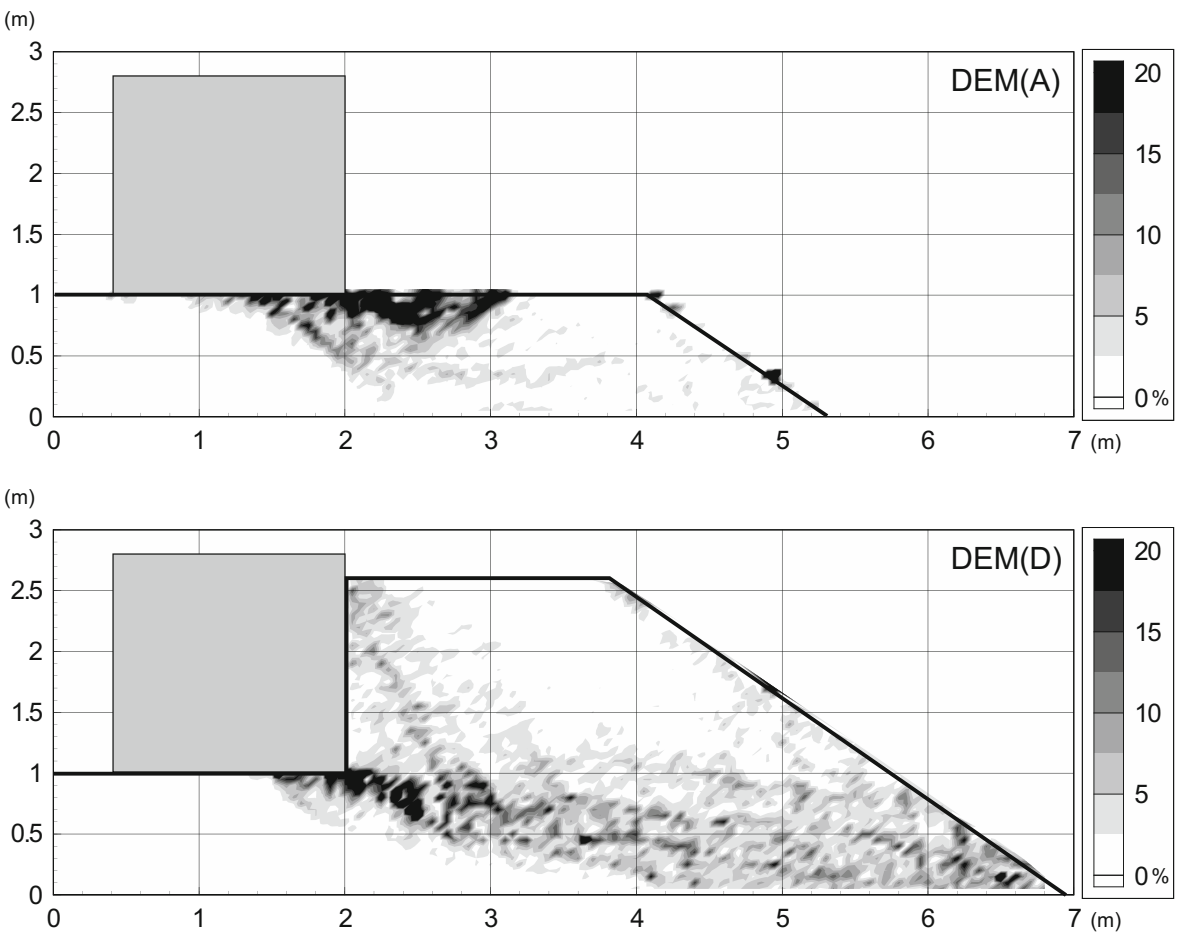

Fig. 6 Shear strain distribution at the horizontal displacement of $150 \mathrm{~mm}$ 


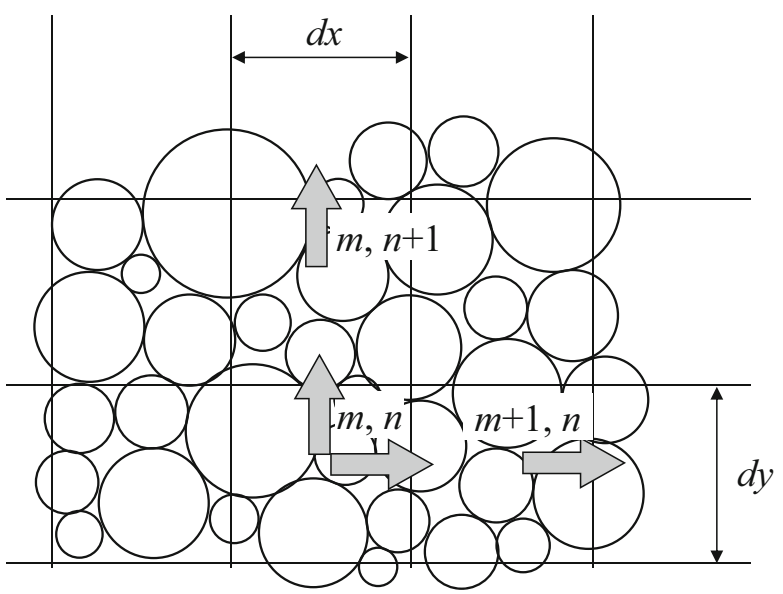

Fig. 7 Average displacement in cells

where $\gamma_{m n}$ is shear strain of the cell $(m, n) ; d x$ and $d y$ are cell dimensions $(0.05 \mathrm{~m}), u_{m, n}$ and $u_{m+1, n}$ are displacements of the cells $(m, n)$ and $(m+1, n)$ in the $x$-direction; and $v_{m, n}$ and $v_{m, n+1}$ are displacements of the cells $(m, n)$ and $(m, n+1)$ in the $y$-direction. Figure 6 shows the failure occurs locally at the ground surface in the case of DEM(A). On the other hand, in the case of DEM(D), the failure occurs in the rubble mound and extends to the slope. The shear characteristics are very similar to the experimental observations. Namely, it can be understood that the parameters in Table 2 are appropriate to simulate the model test.

\section{Overflow Simulations and Modeling Seepage Force in DEM}

In general, uplift force on the bottom of a caisson and seepage force in a rubble mound simultaneously occur during a tsunami overflow. One of the objectives in the present study is to distinguish their effects. To evaluate their forces, numerical simulations on a caisson-type breakwater under a tsunami overflow have been performed using the CADMAS-SURF (SUper Roller Flume for Computer Aided Design of Marine Structure), which is a software for incompressible viscous fluid flow problems using a finite differential method based on the Navier-Stokes equations [10]. In addition, in order to simulate the free surface, volume of fluid (VOF) method is applied. In Japan, the program is commonly used for maritime structural design. Figure 8 indicates the model of the overflow simulation. The flow resistance in the rubble mound was given by the Dupuit-Forchheimer equation as follows:

$$
\begin{gathered}
-\frac{1}{\rho_{\mathrm{w}}} \frac{\partial p}{\partial x}=u(a+b|u|) \\
a=a_{0} \frac{\left(1-\gamma_{v}\right)^{3}}{\gamma_{v}^{2}} \frac{\nu}{d^{2}} \\
b=b_{0} \frac{\left(1-\gamma_{v}\right)^{3}}{\gamma_{v}^{3}} \frac{\nu}{d}
\end{gathered}
$$




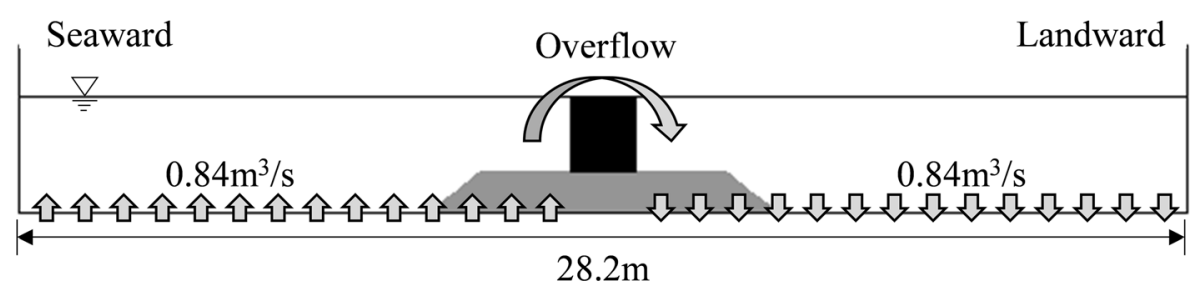

Fig. 8 Model of the overflow simulation

where $\rho_{\mathrm{w}}$ is the density of water, $p$ is the pressure, $u$ is the velocity, $\gamma_{v}$ is the porosity of the rubble mound, $v$ is the kinematic viscosity, and $d$ is the diameter of the rubble mound. Two dimensionless coefficients $a_{0}$ and $b_{0}$ are constants and determined according to experience. In this study, $a_{0}$ and $b_{0}$ were given as 1500 and 3.6, respectively, according to the past study [11]. In this simulation, a model of sandy seabed was ignored since it can be assumed that the permeability of sand is greatly lower than that of rubble mound and the seepage flow hardly occurs through the seabed.

When excess pore water pressure is generated due to hydraulic gradient in a rabble mound, the effective stress decreases. The reduction of the effective stress is regarded as the reduction of the effective weight of the particle. It has been experimentally and numerically revealed that the hydraulic gradient was greater in the horizontal direction than the vertical direction [5, 6]. Moreover, the light boiling has been observed, where the local hydraulic gradient exceeded the critical hydraulic gradient $i_{\mathrm{cr}}[6]$. Therefore, it can be assumed that the $i_{\mathrm{cr}}$ is the appropriate index for the reduction of effective stress or the increase of excess pore water pressure. At the beginning of the investigation, the local hydraulic gradient in the rubble mound was calculated. In order to incorporate the effect of seepage into DE analysis, according to the local hydraulic gradient, the particle density of rubble mound was reduced in DEM.

Generally, tsunamis are generated by earthquakes, submarine landslides, volcanic eruptions, and others. After the generation of tsunami wave, its propagation and its transformation occurs. They vary with each different coast or harbor since they are associated with the bottom topography. Thus, for a detailed damage assessment, the processes should be considered in numerical simulations. The present study focuses on the effect of seepage in a rubble mound on the bearing capacity. Therefore, in these simulations, the tsunami was simulated as a different water level between the offshore and the onshore sides. Water was supplied from the bottom boundary of the offshore side and discharged from that of the onshore side at a rate of $0.84 \mathrm{~m}^{3} / \mathrm{s}$ as indicated in Fig. 8. The overflow simulations were performed for $60 \mathrm{~s}$. As shown in Fig. 9, the water surface elevations were almost constant in $30 \mathrm{~s}$ and the water level difference was approximately $1.2 \mathrm{~m}$ (12 $\mathrm{m}$ at prototype scale).

Figure 10 shows the distribution of local hydraulic gradient averaged from 30 to $60 \mathrm{~s}$. The hydraulic gradient is 0.7 at the onshore edge of the caisson.

On the basis of the local hydraulic gradient, the density of particle was reduced as following equations:

$$
\begin{gathered}
\rho_{s s}=\rho_{s} \frac{i_{c}-i_{l}}{i_{c}} \\
i_{c}=\frac{G_{s}-1}{1+e}
\end{gathered}
$$




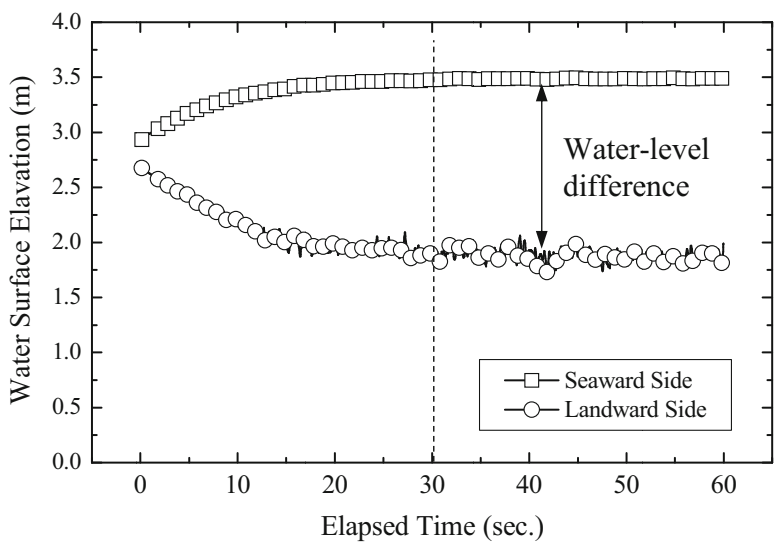

Fig. 9 Changes of the water surface elevation $(D=2.1 \mathrm{~m})$

where $\rho_{s s}$ is the particle density assuming the effect of seepage, $\rho_{s}$ is the particle density, $i_{c}$ is the critical hydraulic gradient, $i_{l}$ is the local hydraulic gradient of the $l$ th particle in DEM, $G_{S}$ is the specific gravity of gravel, and $e$ is the void ratio. The parameter $i_{l}$ is estimated like this,

$$
i_{l}=\sum_{j=1}^{n} w_{j} i_{j}
$$

where $n$ equals the number of recorded points in the overflow simulation, $i_{j}$ is the hydraulic gradient of the recorded point, and $w_{j}$ is the weight of the recorded point. The weight was proposed by Franke and Nielson [12] as

$$
w_{j}=\frac{\left(\frac{R-r_{j}}{R r_{j}}\right)^{2}}{\sum_{k \neq j}\left(\frac{R-r_{k}}{R r_{k}}\right)^{2}}
$$

where $r_{j}$ and $r_{k}$ are the distance from the interpolated point to the recorded point as shown in Fig. 11 and $R$ is the distance from the interpolated point to the most distant recorded point. The distribution of particle density in the DEM is shown in Fig. 12.

\section{Simulation Cases}

Table 3 indicates the list of simulation cases performed in this study. In order to distinguish influencing factors, three types of conditions were assumed. As mentioned

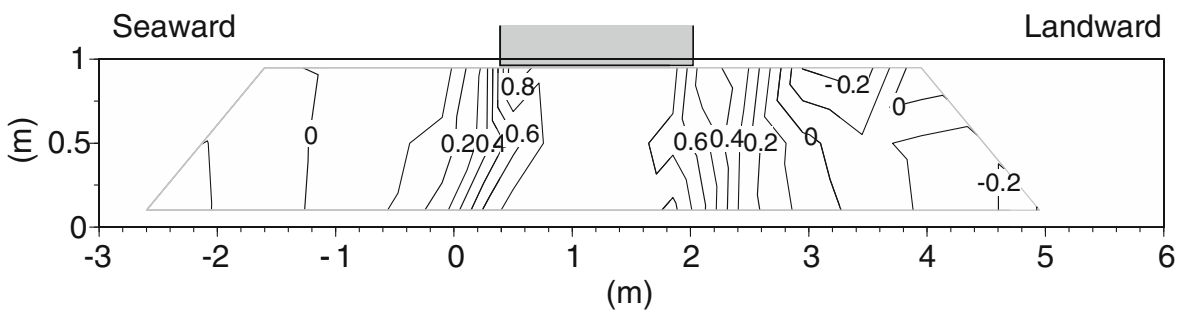

Fig. 10 Distribution of the hydraulic gradient in rubble mound $(D=2.1 \mathrm{~m})$ 


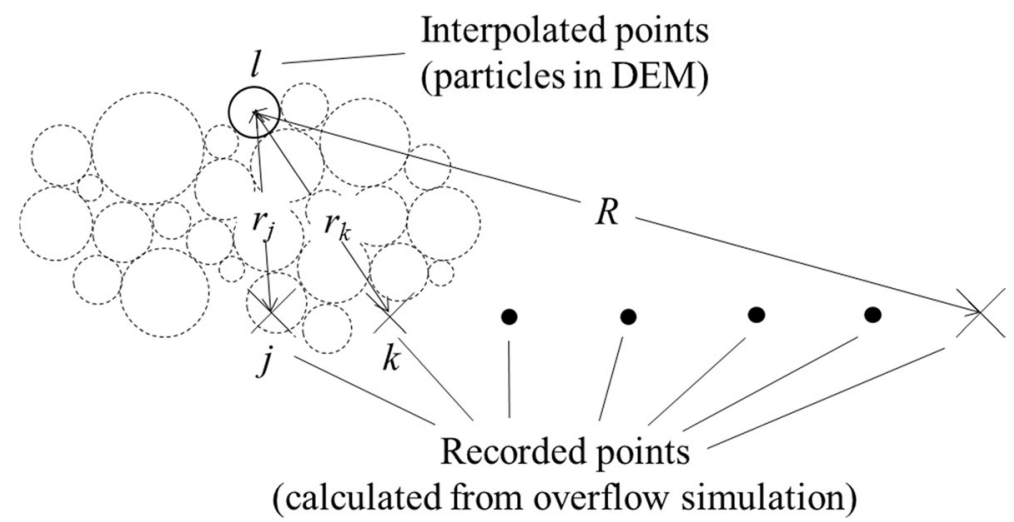

Fig. 11 Distance from an interpolated point to recorded points

above, the effect of the seepage force was reflected as the reduction of the particle density of the rubble mound. The uplift forces were determined on the basis of the results of overflow simulations as well as the seepage force. Figure 13 shows the uplift pressure acting on the bottom of the caisson. The uplift pressure is approximately $12 \mathrm{kN} / \mathrm{m}^{2}$ on the seaward end of the caisson. The pressure level is equal to the water level difference. On the other hand, the uplift pressure is approximately $0 \mathrm{kN} / \mathrm{m}^{2}$ on the landward end of the caisson. It linearly changes and the distribution can be assumed as a simple triangle shape.

To investigate the effect of the location of the caisson on the bearing capacity, the distance of $D$ between the caisson and the edge of mound was changed from 0.6 to $2.1 \mathrm{~m}$. Note that all cases were performed under the submerged conditions unlike in the case of model experiment. The mean water level is $2.6 \mathrm{~m}$ according to the results in Fig. 9, and the submerged weight is $58 \%$ of the caisson model used in the experiment.

\section{Analytical Results and Discussion}

\section{Horizontal Resistance}

Figure 14 shows relations between the average horizontal displacement and the horizontal resistance. The horizontal resistance in the case of 2.1 is about $70 \%$ of that in the case of DEM (A) shown in Fig. 5. This is attributed to the reduction of the selfweight.

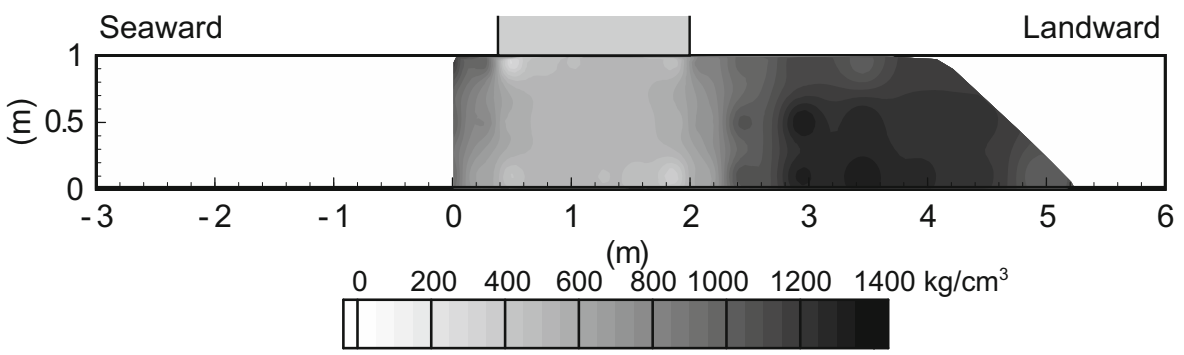

Fig. 12 Distribution of the particle density of the rubble mound $(D=2.1 \mathrm{~m})$ 
Table 3 Analytical conditions

\begin{tabular}{lll}
\hline $\begin{array}{l}\text { Case } \\
\text { name }\end{array}$ & $\begin{array}{l}\text { Distance between } \\
\text { caisson and edge } \\
\text { of rubble mound } D(\mathrm{~m})\end{array}$ & Influencing factor \\
\hline 0.6 & 0.6 & - \\
$0.6 \mathrm{U}$ & 0.6 & Uplift force \\
$0.6 \mathrm{US}$ & 0.6 & Uplift force and seepage force \\
1.1 & 1.1 & - \\
$1.1 \mathrm{U}$ & 1.1 & Uplift force \\
$1.1 \mathrm{US}$ & 1.1 & Uplift force and seepage force \\
2.1 & 2.1 & - \\
$2.1 \mathrm{U}$ & 2.1 & Uplift force \\
$2.1 \mathrm{US}$ & 2.1 & Uplift force and seepage force
\end{tabular}

The horizontal resistance in the case without uplift force is 30 to $40 \%$ larger than that in other case. This implies that the stability of the caisson considerably decreased due to the effect of the uplift force.

Figure 15 shows relations of the maximum horizontal resistance versus the distance between the caisson and the edge of the rubble mound. Figure 15 represents that the horizontal resistance depends on the location of the caisson, which is the distance from the edge of the mound as described by Terashi and Kitazume [7]. The difference is approximately $20 \%$ regardless of the effects of uplift force and seepage force.

In comparison between the cases of the uplift force (U) and the seepage force (US), the reduction of the horizontal resistance can be slightly seen when $D$ is $1.1 \mathrm{~m}$. When $D$ is 0.6 or $2.1 \mathrm{~m}$, there are no differences between U and US. However, in the cases of 0.6 and 2.1 US, unstable behavior is observed as the horizontal resistance drastically drops in Fig. 14. Although the stability is temporarily unbalanced, the horizontal resistance instantaneously recover. The behaviors are likely to be the cause of the settlement of caissons due to the slip between particles.

Figure 16 indicates the vertical displacement with the horizontal displacement. The negative values means the settlement of the caisson model. From the figure, in the cases

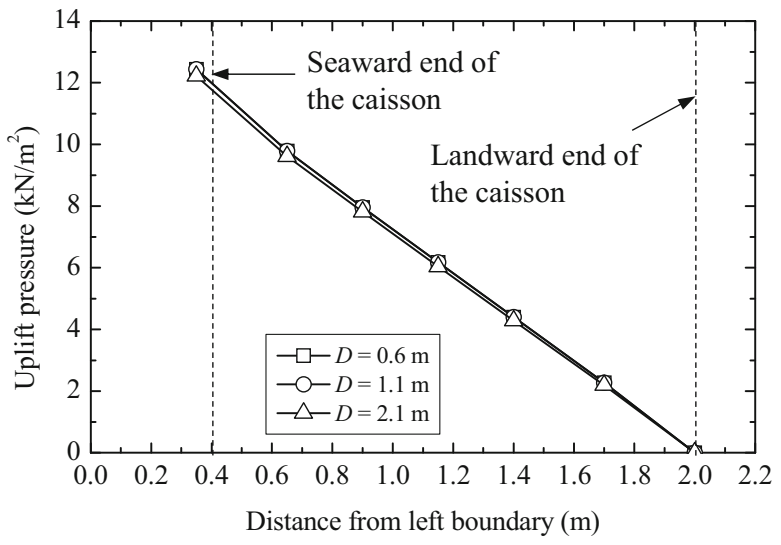

Fig. 13 Uplift pressure on bottom of the caisson 


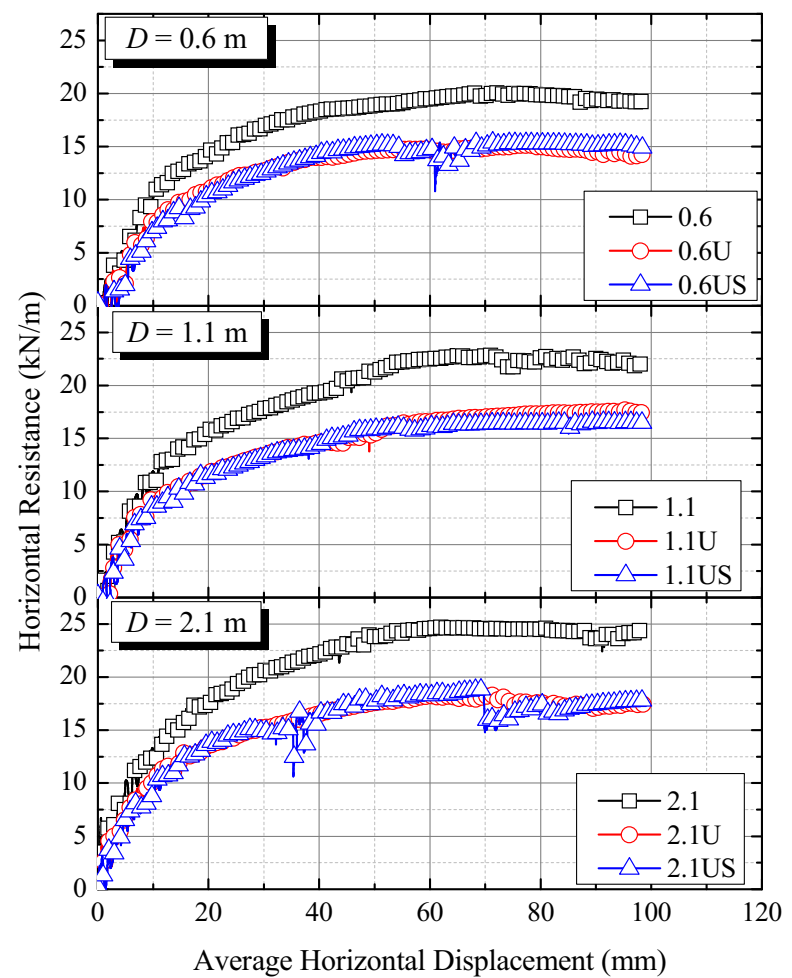

Fig. 14 Relations between the average horizontal displacement and the horizontal resistance

of 0.6 and 2.1 US, the settlement of caisson occurs at the same time as the unstable behavior as seen in Fig. 14. Therefore, it seems that the seepage force affects the deformation of the rubble mound rather than the resistance.

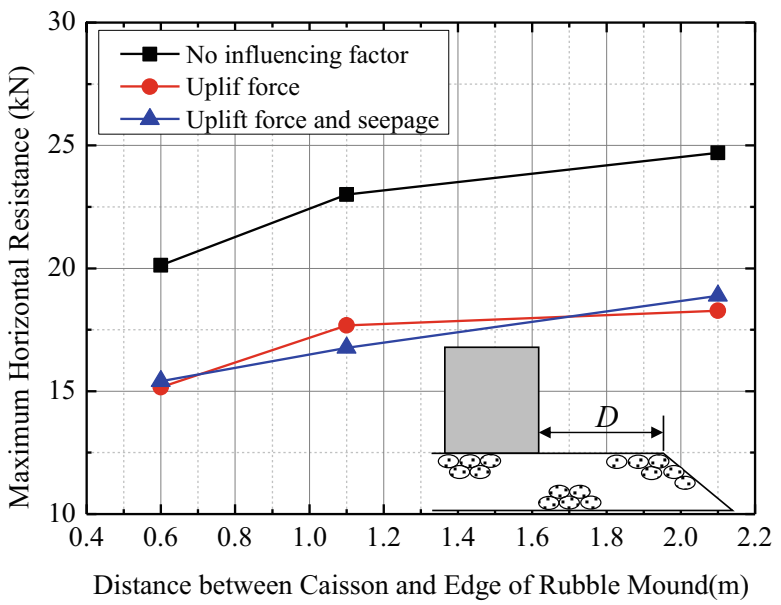

Fig. 15 Relations of the maximum horizontal resistance versus the distance between the caisson and the edge of the rubble mound 


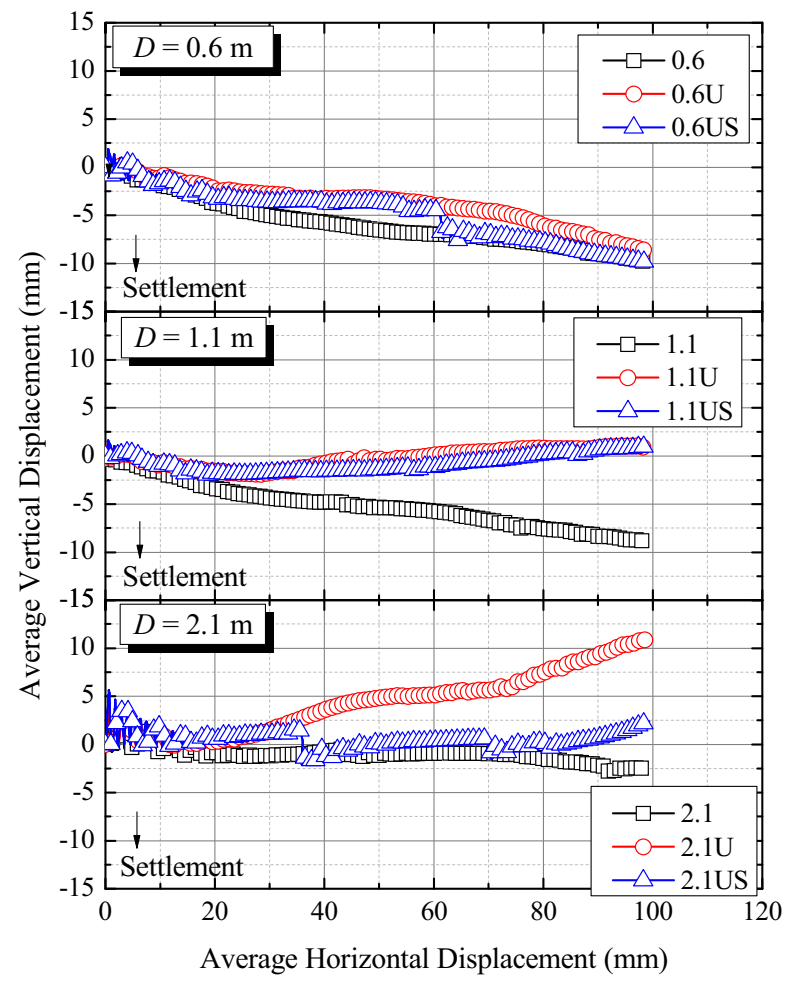

Fig. 16 Relations between the average horizontal displacement and the average vertical displacement

\section{Shear Strain of Rubble Mound}

Figure 17 shows the shear strain distributions of the rubble mound at the horizontal displacement of $100 \mathrm{~mm}$. When $D$ is 0.6 or $1.1 \mathrm{~m}$, the failure surface appears within the rubble mound. In contrast, when $D$ is $2.1 \mathrm{~m}$, the failure occurs locally at the ground surface.

Besides the above discussions, it can be seen that the generation areas of the shear strain in the cases of 0.6 and 1.1 US is larger than that of 0.6 and $1.1 \mathrm{U}$. To evaluate them in a quantitative way, the average shear strain in the rubble mound was calculated. Figure 18 shows relations between the averaged shear strain and the normalized horizontal resistance, which the horizontal resistance $H$ is divided by the self-weight of the caisson $V$. Figure 18 represents that the average shear strain increases due to the seepage force. The increase rates are $13.6 \%$ at $H / V=0.45$ in the case of $0.6 \mathrm{U}, 5.4 \%$ at $H / V=5.0$ in the case of $1.1 \mathrm{U}$, and $18.8 \%$ at $H / V=0.55$ in the case of $2.1 \mathrm{U}$.

\section{Slope Stability by Simplified Bishop Method}

\section{Modeling Seepage Force in Slope Stability Analysis}

In the current design for the bearing capacity of a caisson foundation, the simplified Bishop method is generally used. In order to incorporate the effect of seepage into the 

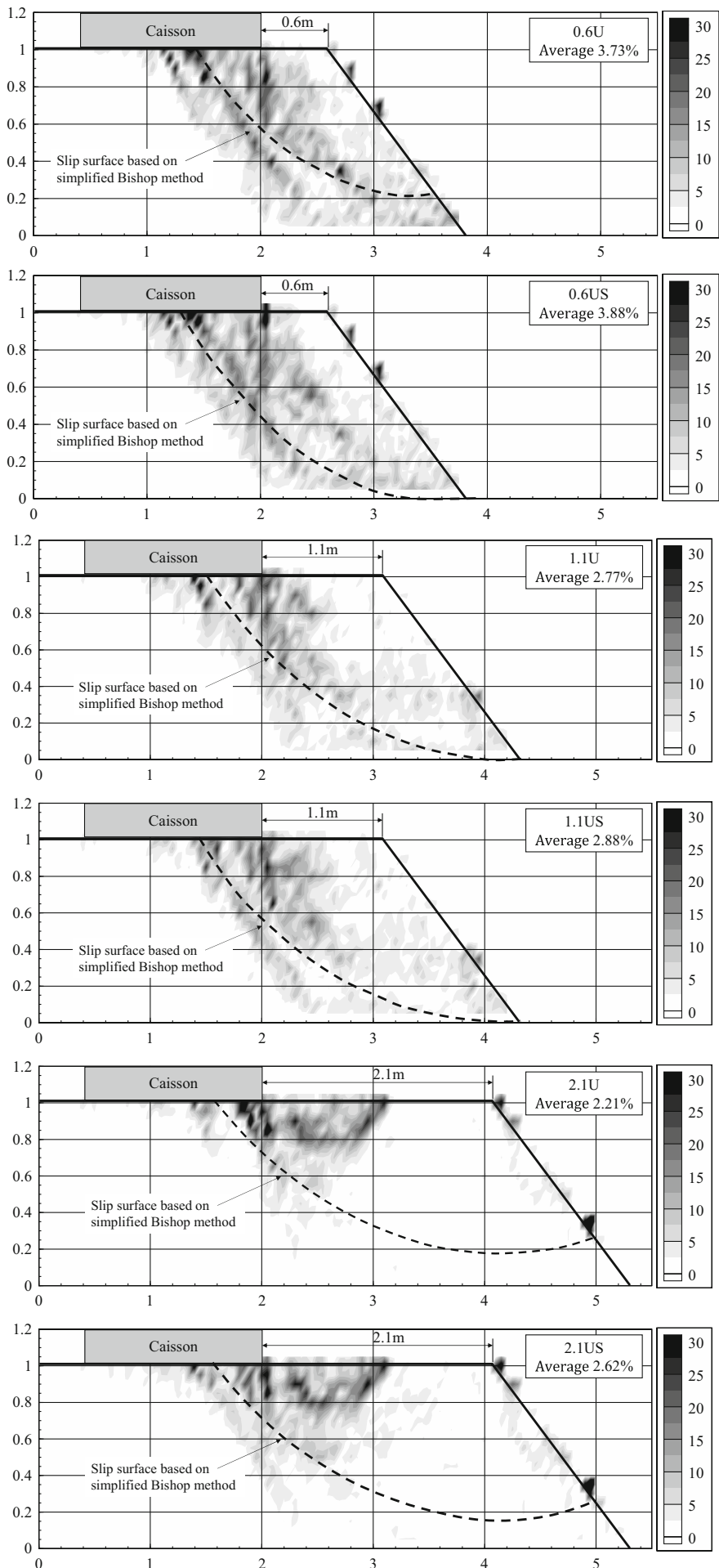

Fig. 17 Shear strain distributions at the horizontal displacement of $100 \mathrm{~mm}$ 


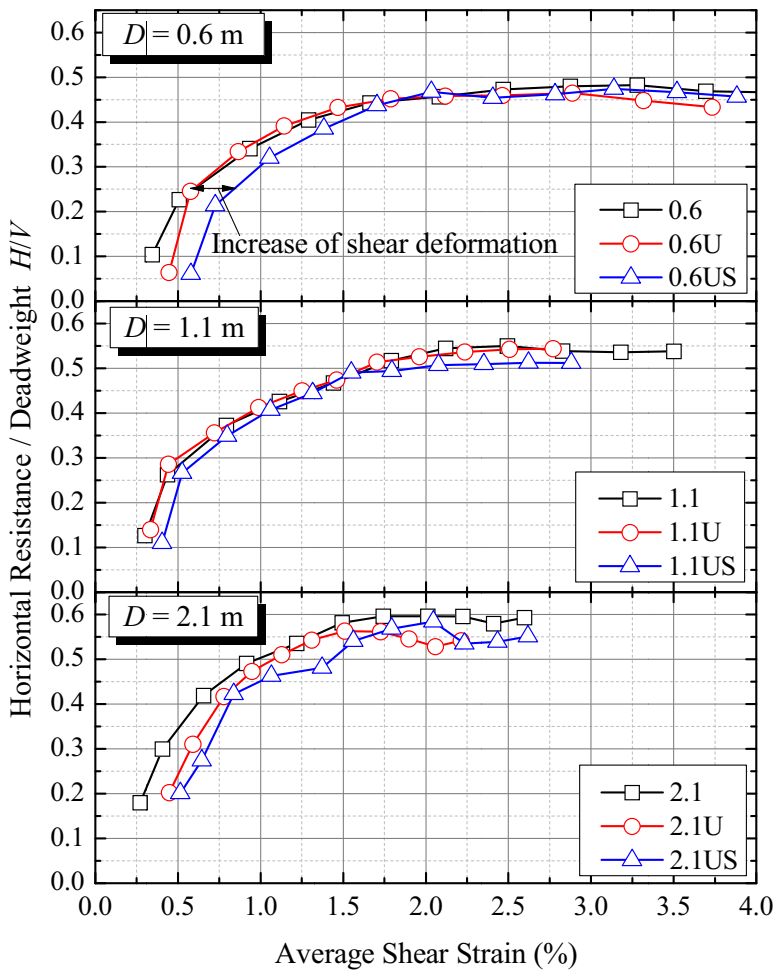

Fig. 18 Relations between the average shear strain and the normalized horizontal resistance

design of the rubble mound, the slope stability was investigated using the simplified Bishop method. As with the case of DE analysis, in the slope stability analysis, the weight of slices was reduced according to the level of seepage force. Namely, a safety factor was given by the following equations:

$$
\begin{gathered}
F=\frac{\sum\left[\left\{c \cdot S+\left(W^{\prime} \cdot R_{f}+q\right) \tan \phi\right\} / m_{a}\right]}{\sum\left[\left\{W^{\prime}+q\right\} \sin \alpha+\beta \cdot P_{h} / r\right]} \\
m_{a}=\left(1+\frac{\tan \phi \tan \alpha}{F}\right) \cos \alpha \\
R_{f}=R_{f 0}+\frac{\left(1-R_{f 0}\right)\left(x-D_{s}\right)}{D_{s}} \quad D_{c}<x \leq\left(D_{c}+D_{s}\right) \\
R_{f}=1 \quad\left(D_{c}+D_{s}\right)<x
\end{gathered}
$$


where $c$ is an apparent cohesion; $S$ is a width of slices; $W$ ' is a submerged unit weight of the slices; $R_{f}$ is a reduction coefficient due to seepage force calculated from Eqs. (11), (12), and (13); $q$ is a surcharge loading; $\varphi$ is a friction angle; $\alpha$ is an angle of the bottom of the slices with the horizontal; $P_{h}$ is horizontal force; $\beta$ is an arm length between the position of horizontal force and a center of circle; $r$ is the radius of the circle; $D_{c}$ is a width of the contact pressure distribution of a caisson; and $D_{s}$ is a range of effect of the seepage force as shown in Fig. 19.

The parameters used in the slope stability analysis are presented in Table 4 . The vertical surcharge $q$ was calculated from $P_{\max }$ and $D_{c}$, which were the contact pressure at the edge of the caisson and the width of the pressure distribution, respectively. The contact pressure of the caisson model was assumed as a simple triangle shape from the results in DE analysis as shown in Fig. 20. The horizontal forces $P_{h}$ were given as the maximum horizontal resistance. Moreover, in all analytical cases, the friction angle was given as $49^{\circ}$ on the basis of the triaxial compression tests, and $R_{f o}$ and $D_{s}$ were, respectively, determined as 0.3 and $1.0 \mathrm{~m}$ according to the results of overflow simulations as shown in Fig. 10.

\section{Results of Slope Stability Analysis}

The results of the slope stability analysis are shown in Table 4 . The safety factors in the cases of $D=0.6$ and $1.1 \mathrm{~m}$ are from 0.9 to 1.0 . Therefore, the slope stability of rubble mound in DEM simulations is able to be estimated by the simplified Bishop method with high accuracy. On the other hand, the circular slip analysis is not applicable to the case of $D=2.1 \mathrm{~m}$ since the safety factor greatly exceeds 1.0 .

Slip surfaces given by the simplified Bishop method are drawn in Fig. 17. In the cases of $D=0.6$ and $1.1 \mathrm{~m}$, the circles are near to the shear strain distributions in DEM. The position in the case of US is deeper than that in the case of U. Namely, the deformation area increases due to the effect of seepage. The tendency can be seen in the

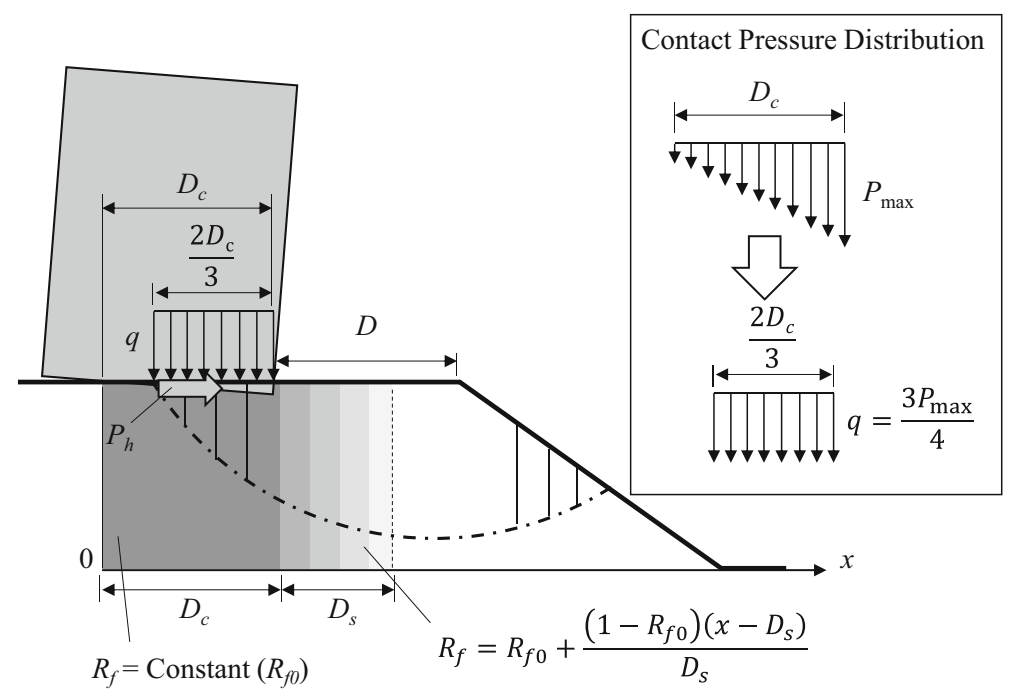

Fig. 19 Circular slip analysis considering seepage force in a rubble mound 
Table 4 Parameters and results of slip analysis

\begin{tabular}{llllll}
\hline Case name & $\begin{array}{l}D \\
(\mathrm{~m})\end{array}$ & $\begin{array}{l}D_{c} \\
(\mathrm{~m})\end{array}$ & $\begin{array}{l}P_{\max } \\
\left(\mathrm{kN} / \mathrm{m}^{2}\right)\end{array}$ & $\begin{array}{l}P_{h} \\
(\mathrm{kN} / \mathrm{m})\end{array}$ & $F$ \\
\hline 0.6 & 0.6 & 1 & 82.4 & 20.1 & 0.995 \\
$0.6 \mathrm{U}$ & 0.6 & 0.7 & 92.2 & 15.2 & 0.964 \\
$0.6 \mathrm{US}$ & 0.6 & 0.9 & 71.7 & 15.4 & 0.913 \\
1.1 & 1.1 & 0.7 & 117.7 & 23.0 & 0.975 \\
$1.1 \mathrm{U}$ & 1.1 & 0.6 & 107.5 & 17.7 & 1.009 \\
$1.1 \mathrm{US}$ & 1.1 & 0.7 & 92.2 & 16.8 & 0.984 \\
2.1 & 2.1 & 0.6 & 137.3 & 24.7 & 1.196 \\
$2.1 \mathrm{U}$ & 2.1 & 0.5 & 129.0 & 18.3 & 1.347 \\
$2.1 \mathrm{US}$ & 2.1 & 0.5 & 129.0 & 18.9 & 1.259 \\
\hline
\end{tabular}

shear strain. By contrast, when $D$ is $2.1 \mathrm{~m}$, the failure mechanism is greatly different from the results in DEM.

In order to investigate the effect of the seepage force, the slope stability analysis were performed under same conditions between U and US. The results are indicated in Table 5. The safety factor decreases by 6.9 to $9.7 \%$. In comparison with the increase of shear strain in Fig. 18, it seems that these results are reasonable.

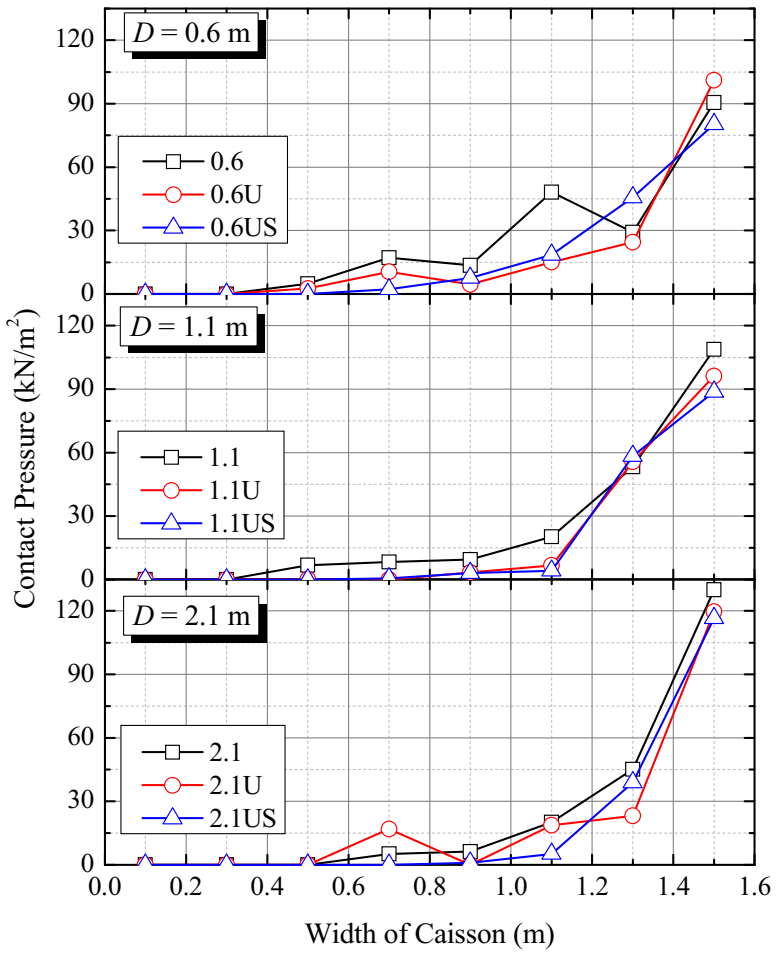

Fig. 20 Contact pressure of the caisson model at the maximum horizontal resistance 
Table 5 Comparison of safety factors between U and US

\begin{tabular}{lllllll}
\hline Case name & $\begin{array}{l}D \\
(\mathrm{~m})\end{array}$ & $\begin{array}{l}D_{c} \\
(\mathrm{~m})\end{array}$ & $\begin{array}{l}P_{\max } \\
\left(\mathrm{kN} / \mathrm{m}^{2}\right)\end{array}$ & $\begin{array}{l}P_{\mathrm{h}} \\
(\mathrm{kN} / \mathrm{m})\end{array}$ & $F$ & $\begin{array}{l}\Delta \\
(\%)\end{array}$ \\
\hline $0.6 \mathrm{U}$ & 0.6 & 0.7 & 92.2 & 15.2 & 0.995 & 9.7 \\
$0.6 \mathrm{US}$ & & & & 17.7 & 0.907 & 1.009 \\
$1.1 \mathrm{U}$ & 1.1 & 0.6 & 107.5 & & 0.944 & 6.9 \\
$1.1 \mathrm{US}$ & & & & & &
\end{tabular}

\section{Summary and Conclusions}

In this study, DE analysis and slip analysis have been carried out in order to investigate the stability of a caisson-type breakwater under tsunami-induced seepage and the influence of distance between the caisson and the edge of rubble mound on the stability. First, the parameters of DEM have been determined on the basis of comparison with large-scale model tests in a past study. Second, overflow simulations based on the VOF method have been performed to evaluate the uplift force and the seepage force due to the hydraulic gradient. Third, DE analysis have been performed considering the effect of the seepage. And finally, in order to incorporate the effect of seepage into the design of the rubble mound, the slope stability was investigated using the simplified Bishop method. As a result, the following conclusions were obtained.

The results of the DE analysis have indicated that the horizontal resistance decreases by 30 to $40 \%$ due to the uplift force. The results of the DE analysis have also revealed the shear deformation of rubble mound increases by approximately 5 to $19 \%$ due to the tsunami-induced seepage.

From the results in slope stability analysis, it has been clear that the safety factors decrease by $7-10 \%$ due to the seepage force, which is approximately consistent with the increase rates of shear deformation. On the other hand, when the distance between the caisson and the edge of rubble mound is large, the local failure occurs at the ground surface. Thus, the circular slip analysis is not applicable to the situation.

As a future work, the design method for a caisson foundation considering the effect of seepage in the case of the large distance between the caisson and the edge of mound should be developed. Moreover, investigations on effects of seepage on the bearing capacity of a caisson foundation with a reinforcement embankment are required.

Acknowledgments This work was carried out using the DEM program which was improved on the basis of "DEMS" developed by Professor Sawada, Kyoto University.

Conflict of Interest The authors declare that they had no conflict of interest.

\section{References}

1. Fujima, K.: Effect of a submerged bay-mouth breakwater on tsunami behavior analyzed by $2 \mathrm{D} / 3 \mathrm{D}$ hybrid model simulation. Nat. Hazards 39, 179-193 (2006) 
2. Arikawa, T., Sato, M., Shimosako, K., Hasegawa, I., Yeom, G.S., Tomita, T.: Failure mechanism of Kamaishi breakwaters due to the Great East Japan Earthquake Tsunami, Proc. of 33rd Conf. on Coastal Eng., No.33, 13p. (2012)

3. Miyake, M., Sumida, H., Maeda, K., Sakai, H., Imase, T.: Development of centrifuge modelling for tsunami and its application to stability of a caisson type breakwater. Ann. J. Civil Eng. Ocean 25, 87-92 (2009)

\section{(in Japanese)}

4. Imase, T., Maeda, K., Miyake, M., Sawada, Y., Sumida, H., Tsurugasaki, K.: Destabilization of a caissontype breakwater by scouring and seepage failure of the seabed due to a tsunami. Proc. of 6th Int. Conf. on Scour and Erosion, 807-814 (2012)

5. Dong, S., Zen, K., Kasama, S., Wang, B., Takesue, A.: Theoretical and experimental study on tsunami induced instability of caisson type composite breakwater, Mem. Faculty Eng., Kyushu Univ. 72(2), 55-68 (2012)

6. Takahashi, H., Sassa, S., Morikawa, Y., Takano, D., Maruyama, K.: Stability of caisson-type breakwater foundation under tsunami-induced seepage. Soils Found. 54(4), 789-805 (2014)

7. Terashi, M., Kitazume, M.: Bearing capacity of a foundation on top of high mound subjected to eccentric and inclined load. Report Port Harbor Res. Institute 26(2), 3-24 (1987)

8. Cundall, P.A., Strack, O.D.L.: A discrete numerical model for granular assemblies. Géotechnique 29(1), 47-65 (1979)

9. Kikuchi, Y., Shinsha, H., Kawamura, K., Eguchi, S.: Effect of the back-filling to the stability of a caisson. J. JSCE, Ser. C 67(4), 474-487 (2011) (in Japanese)

10. Coastal Development Institute of Technology: Research and development of numerical wave channel (CADMAS-SURF). CDIT Library, No. 12, 296 p. (2001) (in Japanese)

11. Maruyama, S., Mistui, J., Matsumoto, A., Hanzawa, M.: Armor damage on harbor-side rubble mound of composite breakwaters against water jet caused by impinging bore-like tsunami. Proc. 34th Conf. Coastal Eng., No. 34, 13p. (2014)

12. Franke, R., Nielson, G.: Smooth interpolation of large sets of scattered data. Int. J. Num. Meth. Eng. 15, 1961-1704 (1980) 